\title{
PENGEMBANGAN DESAIN PEMBELAJARAN BERBASIS PENILAIAN DALAM PEMBELAJARAN MATEMATIKA
}

\author{
Yoppy Wahyu Purnomo \\ FKIP Universitas Muhammadiyah Prof. DR. HAMKA \\ email: yoppy.wahyu@yahoo.com
}

\begin{abstract}
Abstrak: Penelitian ini bertujuan untuk mengembangkan desain pembelajaran berbasis penilaian dan melihat keefektifannya terhadap performa matematika siswa di sekolah dasar. Desain penilaian dikembangkan berdasarkan empat unsur, yaitu fokus pembelajaran, pertanyaan efektif, umpan balik formatif, serta penilaian diri dan sejawat. Tahapan yang direncanakan untuk implementasi pengembangan meliputi tahap inisiasi, konsolidasi, dan penanaman. Penelitian ini mendeskripsikan hasil pada tahapan pertama sebagai langkah awal untuk tahapan-tahapan selanjutnya. Performa matematika diukur dengan tes kemampuan pemecahan masalah dari 37 siswa kelas tiga sekolah dasar yang dengan suka rela berpartisipasi dalam penelitian ini. Data kemampuan pemecahan masalah diperoleh dengan menggunakan pre-test dan post-test. Analisis dilakukan lewat statistik deskriptif, uji normalitas, dan statistik nonparametrik (Wilcoxon Signed Rank) dengan program SPSS 21. Hasil penelitian ini menemukan bahwa terdapat peningkatan kemampuan pemecahan masalah matematika siswa sekolah dasar melalui desain penilaian yang telah dikembangkan.
\end{abstract}

Kata Kunci: penilaian, pembelajaran berbasis penilaian, pemecahan masalah, pembelajaran matematika

\section{DEVELOPING AN ASSESSMENT-BASED LEARNING DESIGN IN MATHEMATICS EDUCATION}

\begin{abstract}
This research was aimed to develop an assessment-based learning design and to investigate the effectiveness of the mathematical performance of elementary school students. The design was developed based on a framework consisting of the learning focus, effective questions, formative feedback, and self-and peer-assessment. The stages of the development included the initiation stage, consolidation, and the embedding stage. This study was to describe the results of the initiation stage as the first step. The mathematical performance was measured using a test of a problem-solving abilities. The subjects consisted of 38 third-grade students selected based on purposive sampling. The problemsolving ability data were gathered using the pre-test and the post-test. This study found that there was an increase in the mathematical problem solving ability of elementary school students through the assessment-based learning design.
\end{abstract}

\section{PENDAHULUAN}

Perspektif penilaian dalam konteks pendidikan dapat dibedakan menjadi dua bentuk, yakni budaya pengujian dan budaya penilaian (Wolf, Bixby, Glenn, \& Gardner, 1991; Kleinsasser, 1995; Delandshere \& Jones, 1999; Dochy \& Segers, 2001; Alonso-Tapia, 2002; Baartman, 2008). Budaya pengujian berkembang dengan tujuan yang mendasar yakni untuk mengidentifikasi sejumlah pengetahuan yang "disimpan" dalam pikiran siswa. Di sisi lain, budaya penilaian memiliki tujuan mendasar yakni menyediakan informasi atau umpan balik baik ke- pada siswa maupun guru untuk memandu cara belajar dan mengajar untuk mencapai tujuan bersama.

Dalam konteks pendidikan di Indonesia, budaya pengujian lebih dominan dalam proses pembelajaran. Hal ini dapat terlihat dari teknik evaluasi yang dilakukan oleh guru, sekolah, maupun pemerintah yang lebih berorientasi pada pengetahuan hafalan dan penguasaan kemampuan tingkat rendah. Dalam budaya pengujian, pembelajaran dipersepsikan sebagai proses akuisisi fakta, aturan, dan keterampilan (Delandshere \& Jones, 1999) sehingga penilaian lebih cende- 
rung dilihat sebagai cara untuk memberikan sanksi dan verifikasi melalui tes beresiko tinggi (high-stake testing). Dengan kata lain, pilihan umpan balik yang dilakukan guru sebagai pertanggungjawabannya lebih kepada pemberian skor atau ranking yang diberikan setelah pengujian selesai. Hal ini memberikan tekanan dan membangun keyakinan guru untuk mengambil pilihan mengajar yang bersifat superfisial dan fokus pada apa yang akan diujikan daripada membangun pengetahuan siswa secara konstruktif.

Paradigma penilaian sebagai cara untuk mengidentifikasi sejumlah pengetahuan yang "disimpan" dalam pikiran siswa menimbulkan pertanyaan besar, yakni apakah proses penilaian hanya dipandang sebagai sebuah pertanggungjawabkan apa yang telah dilakukan oleh guru dan siswa di kelas? Apakah pengajaran yang dilakukan hanya untuk diujikan (teaching to test)? Apakah penilaian (melalui pengujian) yang dilakukan telah merefleksikan hasil pembelajaran secara keseluruhan? Penilaian yang hanya dipandang sebagai cara memberitahukan kepada siswa dengan pemberian nilai atau skor pada akhir satuan pembelajaran mengakibatkan subjektivitas yang bias dan tidak menguntungkan pada peningkatan kualitas pembelajaran, di antaranya (1) mendorong pembelajaran secara hafalan dan superfisial; (2) tujuan utama penilaian lebih dipandang sebagai kompetisi, membandingkan antara siswa satu dengan yang lain ketimbang perbaikan personal; (3) tidak memperhatikan kesulitan belajar yang mungkin dialami siswa; (4) memisahkan penilaian dalam proses pembelajaran, (5) menjadi pendorong pada kecemasan berlebih, dan (6) berpengaruh pada rendahnya self-esteem dan self-beliefs sebagai pebelajar (Black \& William, 2006; Budiyono, 2010).

Belajar merupakan proses interaktif di mana siswa mencoba untuk memahami informasi baru dan mengintegrasikannya ke dalam apa yang mereka sudah ketahui (Earl, 2003; Western and Northern Canadian Protocol for Collaboration in Education [WNCP], 2006). Peran penilaian dalam pembelajaran diperlukan untuk mengukur apa yang siswa ketahui dan perlukan berdasarkan pada data yang dikumpulkan yang berfungsi sebagai bukti belajar. Di samping itu, penilaian digunakan untuk menginformasikan kepada guru untuk merefleksikan pengajarannya dan membuat perbaikan menuju tujuan yang ingin dicapai. Dengan demikian, penilaian tidak hanya bertujuan untuk pemberian skor atau ranking, tetapi juga upaya untuk menyediakan umpan balik kepada siswa maupun guru untuk melakukan perbaikan belajarmengajar sesegera mungkin untuk mencapai tujuan bersama. Hal ini mengandung makna bahwa penilaian selalu menjadi bagian terintegrasi dalam proses pembelajaran serta menjadi bagian krusial untuk membantu siswa dan guru dalam meningkatkan efektivitas belajar-mengajar.

Beberapa penelitian mengungkapkan hasil positif terkait peran penilaian sebagai pendamping alami dalam pembelajaran matematika (misalnya, Chueachot, Srisa-ard, \& Srihamongkol, 2013; Balan, 2012). Lebih dari itu, Black dan William (1998) melalui studi analisis terhadap 250 penelitian tentang classroom formative assessment yang diterbitkan antara 1987 dan 1998 menemukan bahwa beberapa studi menunjukkan bukti kuat bahwa penilaian dapat membantu siswa untuk meningkatkan standar dan prestasi mereka. Dengan kata lain, fokus penilaian yang terintegrasi dalam pembelajaran lebih kepada bagaimana menghasilkan peningkatan substansial dalam hasil belajar siswa daripada hanya digunakan untuk mengukur dan melihat hasil belajar. Meskipun demikian, beberapa penelitian di atas belum mengungkapkan secara rinci bagaimana strategi penilaian yang digunakan. Hal ini mendorong penelitian ini untuk mengembangkan desain pembelajaran yang mencakup strategi-strategi penilaian untuk mendukung pembelajaran matematika, khususnya di sekolah dasar. Dengan demikian, penelitian ini bertujuan untuk mengembangkan pembelajaran berbasis penilaian untuk mendukung pembelajaran matematika di sekolah dasar. Adapun tujuan khusus dalam penelitian ini yakni untuk melihat apakah terdapat peningkatan performa matematika siswa sekolah dasar melalui implementasi pembelajaran berbasis penilaian yang dikembangkan 
Istilah pembelajaran berbasis penilaian atau assessment based learning $(A B L)$ dalam penelitian ini mengacu pada peran penilaian sebagai bagian terintegrasi dalam proses pembelajaran dan digunakan untuk mewadahi tujuan penilaian yang mencakup assessment as learning $(\mathrm{A} a \mathrm{~L})$, assessment for learning ( $\mathrm{A} f \mathrm{~L})$, dan assessment of learning (AoL). Ketiga bentuk penilaian tersebut memiliki kontribusi masingmasing dalam pembelajaran tetapi dalam cara yang sangat berbeda sehingga ketiganya lebih dipandang sebagai tujuan daripada suatu metode untuk menetapkan hasil yang diinginkan dalam proses pembelajaran (Earl, 2003; WNCP, 2006). Lebih lanjut, WNCP (2006) menyatakan bahwa jika fokus utama penilaian ingin meningkatkan pembelajaran untuk semua siswa, peran $\mathrm{A} a \mathrm{~L}$ dan $\mathrm{A} f \mathrm{~L}$ perlu mendapatkan penekanan yang lebih tinggi daripada AoL. Komposisi $\mathrm{A} a \mathrm{~L}, \mathrm{~A} f \mathrm{~L}$, dan $\mathrm{A} o \mathrm{~L}$ yang proporsional sebagai upaya untuk meningkatkan pembelajaran dapat diilustrasikan dalam Gambar 1.

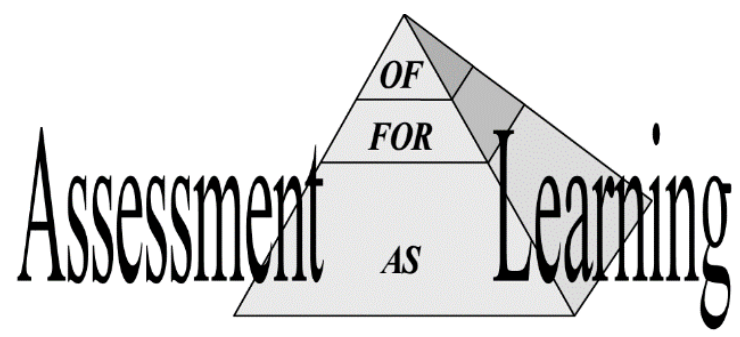

\section{Gambar 1. Piramida Komposisi Penilaian yang Proporsional (WNCP, 2006: 15)}

Terdapat setidaknya empat unsur utama yang harus diperhatikan dalam mengembangkan $\mathrm{A} B \mathrm{~L}$ sehingga menghasilkan tujuan untuk menghantarkan siswa belajar mencapai pemahaman, yakni fokus pembelajaran, pertanyaan efektif, umpan balik formatif, penilaian diri dan sejawat (Black dkk, 2003, 2004; Lee, 2006; Council for the Curriculum Examinations and Assessment [CCEA], 2009).

\section{METODE}

Penelitian ini menggunakan metode pengembangan yang mencakup lima langkah berikut. Pertama, studi literatur, yang digunakan untuk menetapkan landasan dalam mengem- bangkan desain. Kedua, focus group discussion, langkah ini dilakukan untuk memperoleh masukan dari akademisi dan praktisi. Peneliti mengundang rekan-rekan sejawat dosen PGSD dan dua guru sekolah dasar dalam forum diskusi dengan desain seminar terbatas dan sesi tanya jawab. Ketiga, konsultasi dengan pakar, berdasarkan hasil pada tahapan sebelumnya, kemudian dikonsultasikan kepada pakar untuk memeroleh masukan dan validasi desain. Keempat, revisi, beberapa masukan dari pakar dijadikan dasar untuk perbaikan dan kemudian membuat koneksi antara desain yang telah direvisi dengan kajian literatur yang terkait. Kelima, eksperimen dalam ruang lingkup terbatas, peneliti mengujicobakan dengan ruang lingkup terbatas dengan fokus untuk melihat apakah terdapat peningkatan performa matematika siswa sekolah dasar melalui implementasi ABL.

Salah satu sekolah dasar di Ibu Kota dipilih dalam penelitian ini. Tiga puluh delapan siswa kelas tiga terdiri dari 23 perempuan dan 15 laki-laki bersedia dengan sukarela dan tanpa paksaan mengikuti seluruh kegiatan penelitian yang dilakukan selama 12 minggu pada tahun ajaran 2014-2015.

Keefektifan desain $\mathrm{A} B \mathrm{~L}$ terhadap performa matematika diukur dengan menggunakan instrumen tes kemampuan pemecahan pemecahan masalah pada topik operasi bilangan cacah sampai tiga angka. Validitas instrumen dilakukan dengan diskusi antarpeneliti, kemudian dikonsultasikan kepada ahli. Instrumen ini terdiri dari tiga soal yang menggunakan pedoman rubrik untuk pemberian skor. Setiap soal memiliki skor 4 untuk kriteria jawaban yang memenuhi masing-masing indikator, yakni (1) memahami dengan benar dan tepat maksud dari setiap pertanyaan tersebut; (2) menerapkan pengetahuan yang tepat untuk menyelesaikan masalah; (3) menerapkan langkah-langkah yang tepat ketika melakukan perhitungan; (4) menghasilkan jawaban yang tepat. Dengan demikian, skor maksimal untuk instrumen tes ini adalah 12.

Penelitian ini menggunakan tes sebanyak dua kali, yaitu pre-test yang dilakukan sebelum perlakuan dan post-test yang dilakukan setelah 
perlakuan. Analisis data dalam penelitian ini menggunakan bantuan perangkat lunak statistik SPSS versi 21. Data skor pre-test dan post-test dianalisis secara deskriptif untuk melihat skor rata-rata dan deviasi standar. Sebelum digunakan untuk menguji hipotesis, uji prasyarat dilakukan untuk mengetahui apakah sebaran skor pre-test dan post-test berdistribusi normal. Statistik parametrik digunakan jika uji prasyarat terpenuhi, namun jika tidak demikian, statistik nonparametrik dengan uji Wilcoxon Signed Rank dilakukan untuk menguji hipotesis. Hipotesis yang diuji dalam penelitian ini adalah sebagai berikut.

$\mathrm{H}_{\mathrm{a}}$ : Terdapat peningkatan kemampuan pemecahan masalah matematis siswa sekolah dasar setelah dikenai pembelajaran berbasis penilaian.

$\mathrm{H}_{0}$ : Tidak terdapat peningkatan kemampuan pemecahan masalah matematis siswa sekolah dasar setelah dikenai pembelajaran berbasis penilaian.

\section{HASIL DAN PEMBAHASAN}

Langkah pengembangan dalam implementasi $\mathrm{A} B \mathrm{~L}$ di kelas mengacu apa yang disarankan CCEA (2009), yakni tahap inisiasi, konsolidasi, dan penanaman. Tahapan inisiasi menjadi sangat masuk akal untuk memungkinkan peneliti dan/atau guru untuk memulai dan mencoba strategi dari beberapa unsur $\mathrm{A} B \mathrm{~L}$ daripada mencoba untuk memperkenalkan strategi seluruhnya. Hal ini juga masuk akal untuk tidak terburu-buru untuk melanjutkan ke tahapan selanjutnya. Pada tahap konsolidasi, guru mengidentifikasi manfaat dan biasanya mulai berpikir tentang langkah-langkah berikutnya dalam pengembangan ABL. Dengan kata lain, dapat berpindah ke unsur $A B L$ yang lain atau meningkatkan frekuensi penggunaannya atau mengkombinasikannya. Pada tahap penanaman, memungkinkan guru sudah memiliki pengalaman menggunakan strategi di keempat unsur $\mathrm{A} B \mathrm{~L}$. Pada tahap ini, pengambilan keputusan tentang strategi terbaik dalam konteks berbeda menjadi sebuah acuan, dan perbaikan jelas yang berhubungan dengan praktik di lapangan.
Penelitian ini mendeskripsikan hasil pada tahapan pertama, yakni tahap inisiasi, yang digunakan sebagai langkah awal untuk tahapantahapan selanjutnya. Hasil dari tahap inisiasi ini difokuskan untuk mengembangkan desain pembelajaran berbasis penilaian dan memperoleh kesimpulan dari hasil uji coba dengan ruang lingkup terbatas.

\section{Desain Pembelajaran Berbasis Penilaian}

Hasil berupa desain pembelajaran berbasis penilaian diperoleh dari serangkaian aktivitas seperti yang telah diutarakan di depan. Desain pembelajaran diklasifikasikan berdasarkan empat unsur $\mathrm{A} B \mathrm{~L}$ dan tidak bersifat mengikat/kaku sebagai urutan pembelajaran. Desain awal yang telah direvisi dan sengaja dihubungkan kembali dengan telaah literatur terkait untuk memperkuat konstruksi desain dapat dilihat pada Tabel 1.

\section{Peforma Matematika Siswa Sekolah Dasar Sebelum dan Setelah Perlakuan}

Hasil analisis secara deskriptif dari skor pre-test dan post-test digunakan untuk melihat skor rata-rata dan deviasi standar. Tabel 2 menunjukkan statistik deskriptif yang dianalisis dengan menggunakan bantuan SPSS versi 21.

Sebelum melakukan uji hipotesis, dilakukan uji normalitas sebaran skor dengan menggunakan bantuan SPSS versi 21 yang hasilnya ditunjukkan oleh Tabel 3. Perhatikan bahwa nilai signifikansi dari uji statistik Shapiro-Wilk untuk data pre-test dan post-test kurang dari $0,05(p<0,05)$ sehingga sebaran skor pre-test dan post-test tidak berdistribusi normal. Dengan demikian, uji hipotesis yang dipilih adalah uji non-parametrik.

Mengacu pada data pre-test dan post-test yang tidak berdistribusi normal, maka uji hipotesis dilakukan dengan menggunakan uji nonparametrik. Uji non-parametrik menggunakan uji statistik Wilcoxon Signed Rank dengan bantuan SPSS versi 21 yang dapat ditampilkan pada Tabel 4 dan Tabel 5 . 
Tabel 1. Desain Pembelajaran Berbasis Penilaian

\begin{tabular}{|c|c|}
\hline Unsur $\mathbf{A B L}$ & Praktik $\mathbf{A} B \mathbf{L}$ \\
\hline $\begin{array}{l}\text { Fokus } \\
\text { Pembelajaran }\end{array}$ & $\begin{array}{l}\text { - Guru merencanakan tujuan dan kriteria sukses berdasarkan kompetensi dasar yang } \\
\text { akan dicapai. } \\
\text { - Disampaikan kepada siswa di awal pembelajaran dan ditampilkan dalam bentuk poster } \\
\text { yang ditempel di sekeliling kelas. } \\
\text { - Kriteria sukses dinegosiasikan dengan siswa dengan mengacu pada poin atau catatan- } \\
\text { catatan yang perlu dikembangkan. }\end{array}$ \\
\hline Pertanyaan Efektif & $\begin{array}{l}\text { - Mengeksplorasi pertanyaan berupa fakta dengan teknik probing questions dan men- } \\
\text { ciptakan respon lanjutan berupa pertanyaan lebih lanjut segera sehingga bukan hanya } \\
\text { untuk memberikan klarifikasi. } \\
\text { - Mengeksplorasi respon siswa terutama contoh jawaban yang salah dan miskonsepsi } \\
\text { umum untuk sumber diskusi kelas. } \\
\text { - Memberikan waktu berpikir dalam pada dua periode penting, yaitu waiting time } 1 \text { dan } \\
\text { waiting time } 2 \text { serta melatih keterampilan "waktu berpikir" kepada anak dalam meres- } \\
\text { pon pertanyaan. Waiting time } 1 \text {, yakni interval antara berakhirnya pertanyaan guru dan } \\
\text { dimulai dari respon siswa, sedangkan waiting time } 2 \text { merupakan akumulasi jeda antara } \\
\text { jawaban/argumen siswa sebelum guru atau siswa lain melakukan elaborasi atau pen- } \\
\text { jelasan lebih lanjut. } \\
\text { - Menggunakan strategi "no hands up" kecuali untuk memberikan kesempatan siswa } \\
\text { untuk mengajukan pertanyaan. } \\
\text { - Menggunakan permasalahan matematika yang terkait dengan konteks dan pengalaman } \\
\text { siswa. }\end{array}$ \\
\hline Umpan Balik & - Memberikan komentar lisan konstruktif dari respon atau jawaban siswa. \\
\hline Formatif & $\begin{array}{l}\text { - Memberi komentar tertulis konstruktif dan mengembalikan hasil pekerjaan siswa } \\
\text { dalam rentang waktu sesegera mungkin. } \\
\text { - Guru menggunakan rubrik untuk memantau poin-poin penting dalam aktivitas } \\
\text { pembelajaran dan sesering mungkin didiskusikan dengan siswa dan orang tua. } \\
\text { - Umpan balik ditekankan pada perbaikan selanjutnya (feed forward) bukan hanya me- } \\
\text { nilai kinerja, yakni mengambil poin penting untuk refleksi diri dan diskusi kelas. }\end{array}$ \\
\hline $\begin{array}{l}\text { Penilaian diri dan } \\
\text { Sejawat }\end{array}$ & $\begin{array}{l}\text { - Menyediakan kesempatan kepada siswa untuk mengomentari respon atas jawaban dan } \\
\text { pertanyaan siswa lain di kelas. Hal ini dapat dilakukan dengan kegiatan presentasi } \\
\text { lisan oleh siswa. } \\
\text { - Guru melakukan verifikasi keyakinan diri siswa dalam belajar dengan menggunakan } \\
\text { beberapa teknik di antaranya "thumbs up" atau "traffic light". } \\
\text { - Menyediakan proses umpan balik sejawat terhadap pekerjaan atau lembar kerja ano- } \\
\text { nim dari siswa lain. } \\
\text { - Menyediakan variasi untuk respon sejawat, seperti menukar teman sejawat. } \\
\text { - Siswa menggunakan mini-rubrik untuk mereka bandingkan dengan tujuan dan kriteria } \\
\text { sukses. }\end{array}$ \\
\hline
\end{tabular}

Tabel 2. Deskripsi Skor Pre-test dan Post-test

\begin{tabular}{lllc}
\hline & N & Mean & Std. Deviation \\
\hline Pre-test & 37 & 1,892 & 2,1053 \\
\hline Post-test & 37 & 4,622 & 3,1033 \\
\hline
\end{tabular}

Tabel 3. Hasil Uji Normalitas

\begin{tabular}{lcccccc}
\hline & \multicolumn{3}{c}{ Kolmogorov-Smirnov $^{\text {a }}$} & \multicolumn{3}{c}{ Shapiro-Wilk } \\
\cline { 2 - 7 } & Statistic & df & Sig. & Statistic & df & Sig. \\
\hline Pre-test & 0,263 & 37 & 0,000 & 0,793 & 37 & 0,000 \\
\hline Post-test & 0,121 & 37 & 0,189 & 0,912 & 37 & 0,006 \\
\hline
\end{tabular}

a. Lilliefors Significance Correction 
Tabel 4. Jangkauan Tanda

\begin{tabular}{|c|c|c|c|c|}
\hline & & $\mathrm{N}$ & Mean Rank & Sum of Ranks \\
\hline \multirow[t]{4}{*}{ postes - pretes } & Negative Ranks & $7^{\mathrm{a}}$ & 7,43 & 52,00 \\
\hline & Positive Ranks & $27^{b}$ & 20,11 & 543,00 \\
\hline & Ties & $3^{c}$ & & \\
\hline & Total & 37 & & \\
\hline \multicolumn{5}{|l|}{ a. postes < pretes } \\
\hline \multicolumn{5}{|l|}{ b. postes $>$ pretes } \\
\hline c. postes $=$ pretes & & & & \\
\hline
\end{tabular}

Tabel 5. Uji Statistik Wilcoxon Signed Rank

\begin{tabular}{cc}
\hline & postes - pretes \\
\hline $\mathbf{Z}$ & $-4,213^{\mathrm{b}}$ \\
Asymp. Sig. & 0,000 \\
(2-tailed) & \\
\hline
\end{tabular}

a. Wilcoxon Signed Ranks Test

b. Based on negative ranks.

Berdasarkan hasil analisis di atas, terlihat bahwa nilai signifikansi kurang dari 0,05 . Dengan demikian, hipotesis null yang menyatakan tidak terdapat peningkatan kemampuan pemecahan masalah tidak diterima. Dengan kata lain, menerima hipotesis alternatif yang berarti bahwa terdapat peningkatan kemampuan pemecahan masalah siswa sekolah dasar setelah dikenai perlakuan berupa pembelajaran berbasis penilaian.

\section{Pembahasan}

Berdasarkan hasil uji hipotesis yang dijelaskan di depan, dapat disimpulkan bahwa implementasi dari pengembangan $\mathrm{A} B \mathrm{~L}$ mampu meningkatkan kemampuan pemecahan masalah secara signifikan. Temuan ini konsisten dengan hasil penelitian yang dilakukan Balan (2012) yang menemukan peningkatan pemecahan masalah matematis melalui implementasi AfL. Penelitiannya mendeteksi bahwa dengan menggunakan AfL, siswa mampu menginterpretasikan masalah dan menggunakan metode matematika yang tepat untuk mengatasinya. Siswa juga menunjukkan perbaikan dalam memberikan alasan terhadap solusi matematika, bagaimana menyajikan solusi dengan cara yang jelas dan mudah diakses, dan cara tepat untuk meng- gunakan simbol, terminologi, dan kaidah matematika.

Kemampuan pemecahan masalah mengharuskan siswa untuk memahami dan menggunakan pengetahuan yang tepat dalam memahami situasi dan konteks permasalahan (Dixon \& Brown, 2012; Sutton, 2003) dan mengkomunikasikan pemahaman matematis mereka (Caswell \& Nisbet, 2005). Kemampuan ini dapat dikembangkan dengan mengeksplorasi pengetahuan siswa melalui pertanyaan efektif dalam desain ABL. Özsoy dan Ataman (2009) menyatakan bahwa pertanyaan efektif berkontribusi terhadap pemecahan masalah, memicu proses berpikir dan merangsang imajinasi. Pertanyaan efektif juga dapat meningkatkan kemampuan berpikir kritis yang digunakan untuk menafsirkan permasalahan secara lebih komprehensif sehingga siswa dapat mengkomunikasikan dan menerapkan pengetahuan yang tepat untuk memecahkan masalah matematis. Hal ini sebagaimana yang dilaporkan oleh Redhana (2012, 2014), yang menyatakan bahwa pertanyaan efektif secara signifikan mampu meningkatkan kemampuan berpikir kritis yang selanjutnya digunakan siswa untuk memecahkan masalah.

Pertanyaan dalam ABL memungkinkan semua siswa merasa bahwa mereka memiliki sesuatu untuk dikatakan karena tidak menekankan pada jawaban yang didasarkan pengetahuan faktual. Hal ini masuk akal karena pertanyaan lebih menekankan bagaimana mengeksplorasi pengetahuan konseptual siswa dalam mengkomunikasikan gagasan. Pertanyaan dalam $\mathrm{A} B \mathrm{~L}$ juga memungkinkan guru memiliki beberapa akses ke dalam alam pikir siswa sehingga dapat melakukan intervensi untuk mengatasi miskon- 
sepsi dan mempromosikan pembelajaran lebih lanjut (Black dkk, 2003, 2004; CCEA, 2009; Redhana, 2014). Hal ini dapat dilakukan oleh guru dengan menindaklanjuti jawaban faktual dari siswa dengan pertanyaan-pertanyaan terbuka yang membimbing mereka mengungkapkan pengetahuan yang lebih mendalam, seperti "Mengapa Anda berpikir bahwa...?" dan "Apakah ada yang punya ide lebih lanjut tentang hal itu?"

Kemampuan pemecahan masalah matematis juga mengharuskan siswa untuk mampu merefleksikan diri ketika mereka terlibat dalam "tugas" (Caswell \& Nisbet, 2005; Schoenfeld, 1992). Kemampuan refleksi diri tersebut berkaitan dengan proses umpan balik yang dapat membantu siswa menyadari potensi kelemahan dalam pemahaman atau pekerjaan, dan bagaimana bekerja untuk meningkatkan pemahaman dan pekerjaan mereka (Carnes, Cardella, \& Diefes-Dux, 2010). Dengan kata lain, umpan balik dalam $\mathrm{A} B \mathrm{~L}$ lebih kepada refleksi diri siswa ke mana akan melangkah? Sejauh mana posisinya terhadap tujuan yang akan dicapai? Bagaimana saya akan melangkah selanjutnya? (Hattie \& Timperley, 2007). Umpan balik dalam $\mathrm{A} B \mathrm{~L}$ juga bukan dalam bentuk skor dan tidak hanya sebatas informasi dari guru ke siswa dan siswa ke guru, namun juga mencakup komentar konstruktif dari sejawat dan menilai diri sendiri.

Proses umpan balik merupakan unsur dalam penilaian diri dan sejawat yang mana keduanya saling bersinergi untuk membantu siswa untuk merefleksikan kemampuan, pengetahuan, dan pekerjaan mereka sehingga membantu memecahkan masalah dengan teliti. Hal ini sebagaimana yang diungkapkan oleh beberapa peneliti bahwa refleksi diri siswa dalam keterlibatannya terhadap tugas pemecahan masalah matematis dapat ditingkatkan dengan menggunakan penilaian diri dan sejawat (misalnya, Evans \& Swan, 2014; Kearney \& Perkins, 2010). Penilaian diri dan sejawat dalam desain ABL dilakukan dengan variasi strategi, di antaranya menyediakan kesempatan kepada siswa untuk mengomentari respon atas jawaban dan pertanyaan siswa lain di kelas. Hal ini dapat dilakukan dengan kegiatan presentasi lisan oleh siswa. Presentasi lisan di kelas matematika merupakan salah satu metode yang mencakup proses penilaian diri dan sejawat (Ma, Millman, \& Wells, 2008) untuk menyediakan kesempatan siswa berpikir tentang matematika, memperkuat argumen mereka, dan bagaimana mengekspresikan matematika dan pemahaman mereka tentang matematika dengan kata-kata mereka sendiri, merefleksikan pemahaman mereka sendiri dan ide-ide orang lain (National Council of Teachers of Mathematics [NCTM], 2000; Lianghuo \& Mei, 2007). Strategi lain untuk menciptakan penilaian diri dan sejawat adalah menggunakan mini-rubrik. Terdapat beberapa alasan untuk menggunakan rubrik dalam desain $\mathrm{A} B \mathrm{~L}$, yakni untuk memandu skoring yang lebih objektif, alat untuk memfasilitasi penilaian diri dan sejawat, menyediakan umpan balik tepat waktu dan terperinci, mendorong berpikir kritis, dan membantu mempertajam fokus belajar siswa (Andrade, 2000; Stevens \& Levi, 2005).

Paradigma teaching to the test dalam proses penilaian yang selama ini berkembang seharusnya dihindari karena tidak menguntungkan untuk kualitas pendidikan. Penggunaan penilaian dalam pembelajaran tidak hanya sekedar menggunakan serangkaian tes, tetapi juga dapat dilakukan dengan beberapa cara yang didasarkan dari prinsip-prinsip penilaian. $\mathrm{A} B \mathrm{~L}$ merupakan penilaian proses yang menggunakan bukti-bukti belajar untuk digunakan siswa dan guru untuk menentukan di mana posisi siswa dalam proses belajarnya, di mana mereka harus melangkah dan bagaimana cara terbaik untuk mencapai tujuan bersama. Dampak positif dari implementasi ABL diharapkan memberikan sumbangsih tak langsung dalam upaya mengubah perspektif budaya pengujian menjadi budaya penilaian sebagai pendamping alami dalam proses pendidikan. Di sisi lain, implikasi dari hasil penelitian dalam ruang lingkup terbatas ini diharapkan menjadi landasan berpijak untuk mengembangkan literasi penilaian dalam pengembangan program pendidikan guru. Hal ini masuk akal karena mengembangkan literasi penilaian berguna membangun keyakinan atau persepsi guru tentang penilaian yang berperan 
penting untuk menuntun mereka dalam mengambil keputusan tentang praktik penilaian yang rasional untuk mendukung proses pembelajaran (Jane, 2012; Pajares, 1992).

\section{Keterbatasan Penelitian}

Keterlibatan guru kelas yang minim menyebabkan peneliti membutuhkan waktu lebih untuk beradaptasi dengan karakteristik siswa dan lingkungannya. Hal ini menjadi dasar penelitian selanjutnya untuk melibatkan guru-guru dalam studi kasus. Terbatasnya topik matematika hanya operasi bilangan sampai tiga angka dan sampel yang dilakukan hanya di kelas III sekolah dasar di wilayah ibu kota tidak dapat digeneralisasikan untuk seluruh topik matematika dan seluruh siswa sekolah dasar sehingga penelitian selanjutnya perlu dikembangkan dengan ruang lingkup yang lebih luas, mencakup kemampuan matematis yang lebih komprehensif dan sampel yang lebih representatif. Keterbatasan lain terletak pada reliabilitas instrumen yang sengaja tidak diujicobakan karena dianalisis dengan panduan rubrik. Namun demikian, validitas isi dan keterbacaan tetap dikedepankan untuk menjamin alat ukur untuk mengukur apa yang harusnya diukur.

\section{PENUTUP}

Berdasarkan temuan yang diperoleh pada penelitian ini, dapat disimpulkan bahwa terdapat peningkatan performa matematika siswa sekolah dasar melalui pembelajaran berbasis penilaian yang dikembangkan, khususnya kemampuan pemecahan masalah matematika. Dengan demikian, selain sebagai alat untuk mengevaluasi capaian siswa setelah mengalami belajar, penilaian juga merupakan pendamping alami untuk meningkatkan pembelajaran matematika.

\section{UCAPAN TERIMA KASIH}

Ucapan terima kasih disampaikan kepada Direktorat Penelitian dan Pengabdian pada Masyarakat, Direktorat Jenderal Pendidikan Tinggi, Kementerian Pendidikan dan Kebudayaan yang telah mendanai penelitian ini melalui program penelitian hibah fundamental sesuai surat perjanjian pelaksanaan penugasan program penelitian nomor: 200/K3/KM/2014, tanggal 7 Mei 2014. Peneliti juga mengucapkan terima kasih kepada Prof. Dr. Didi Suryadi, M.Ed. dan Dr. Acep Kusdiwelirawan, M.Si yang telah memberi masukan dan saran untuk penelitian ini.

\section{DAFTAR PUSTAKA}

Alonso-Tapia, J. 2002. "Knowledge Assessment and Conceptual Understanding", dalam M. Limon \& Mason, L (Eds.), Reframing the Processes of Conceptual Change. Dordretch: Kluwer Academic Publishers. Hlm. 389-413.

Andrade, H. 2000. "Using Rubrics to Promote Thinking and Learning". Educational Leadership, 57 (5), hlm. 13-18.

Baartman, L. K. J. 2008. "Assessing the Assessment: Development and Use of Quality Criteria for Competence Assessment Programmes". Doctoral Dissertation. Utrecht University. The Netherlands.

Balan, A. 2012. "Assessment for Learning: A Case Study in Mathematics Education". Doctoral Thesis. Malmö University. Malmö.

Black, P., \& Wiliam, D. 1998. "Inside the Black Box: Raising Standards through Classroom Assessment". Phi Delta Kappan, 80 (2), hlm. 139-148.

Black, P., \& William, D. 2006. “Assessment for Learning in the Classroom", dalam J. Gardner (Ed.). Assessment and Learning. London, UK: SAGE Publication Ltd. Hlm. 9-26.

Black, P., Harrison, C., Lee, C., Marshall, B., \& Wiliam, D. 2003. Assessment for Learning: Putting it into Practice. Buckingham, UK: Open University Press. 
Black, P., Harrison, C., Lee, C., Marshall, B., \& Wiliam, D. 2004. "Working Inside the Black Box: Assessment for Learning in the Classroom". Phi Delta Kappan, 86 (1), hlm. 8-21.

Budiyono. 2010. "Peran Asesmen dalam Peningkatan Kualitas Pembelajaran". Makalah disajikan dalam Seminar Nasional Pendidikan Matematika, Universitas Sebelas Maret, tanggal 5 Mei 2010.

Carnes, M. T., Cardella, M. E., \& Diefes-Dux, H. A. 2010. "Progression of Student Solutions over the Course of a Model-Eliciting Activity (MEA)". 40th ASEE/IEEE Frontiers in Education Conference, Washington DC, USA.

Caswell, R., \& Nisbet, W. 2005. "Enhancing Mathematical Understanding Through Self-assessment and Self-Regulation of Learning: The Value of Meta-Awareness", dalam P. Clarkson, A. Downton, D. Gronn, M. Horne, A. McDonough, R. Pierce, A. Roche (Eds.), Building Connections: Research, Theory and Practice. MERGA Inc. Hlm. 209-216.

Chueachot, S., Srisa-ard, B., \& Srihamongkol, Y. 2013. "The Development of an Assessment for Learning Model for Elementary Classroom". International Education Studies, 6 (9), hlm. 119-124. doi: 10.5539/ies.v6n9p119.

Council for the Curriculum Examinations and Assessment [CCEA]. 2009. Assessment for Learning: A Practical Guide. Belfast: CCEA Publication.

Delandshere, G., \& Jones, J. H. 1999. "Elementary Teachers' Beliefs about Assessment in Mathematics: A Case of Assessment Paralysis". Journal of Curriculum and Supervision, 14 (3), hlm. 216-240.
Dixon, R. A., \& Brown, R. A. 2012. "Transfer of Learning: Connecting Concepts during Problem Solving”. Journal Technology Education, 24(1). http://scholar.lib.vt.edu/ejournals/JTE/v24n1/dixon.html. (diunduh 14 Februari 2013).

Dochy, F., \& Segers, M. 2001. "Using Information and Communication Technology (ICT) in Tomorrow's Universities and Using Assessment as a Tool for Learning by Means of ICT", dalam H. Van der Molen (Ed.), Virtual University? Educational Environments of the Future. London: Portland. Hlm. 67-83.

Earl, L. 2003. Assessment as Learning: Using Classroom Assessment to Maximise Student Learning. Thousand Oaks, CA, Corwin Press.

Evans, S., \& Swan, M. 2014. "Developing Students' Strategies for Problem Solving". Educational Designer, 2 (7), hlm. 1-31.

Hattie, J., \& Timperley, H. 2007. "The Power of Feedback". Review of Educational Research, 77 (1), hlm. 81-112.

Jane, S. M. 2012. "Sixth Grade Teachers' Conceptions of Classroom Assessment". Literacy Information and Computer Education Journal (LICEJ), 3 (2), hlm. 568575 .

Kearney, S. P. \& Perkins T. 2010. "Developing Students' Capacity for Innovation, Creativity Andcritical Thinking through Contemporary Forms of Assessment: a Case Study in Progress". Paper presented at ATN Assessment Conference, University of Technology, Sydney.

Kleinsasser, A. M. 1995. "Assessment Culture and National Testing". The Clearing House, 68 (4), hlm. 205-210. 
Lee, C. 2006. Language for Learning Mathematics: Assessment for Learning in Practice. Berkshire, England: Open University Press.

Lianghuo, F., \& Mei, Y. S. 2007. "Integrating Oral Presentation into Mathematics Teaching and Learning: An Exploratory Study with Singapore Secondary Students". The Montana Mathematics Enthusiast, Monograph 3, hlm. 81-98.

Ma, X., Millman, R., \& Wells, M. 2008. "Infusing Assessment into Mathematics Content Courses for Pre-Service Elementary School Teachers". Educational Research for Policy and Practice, 7(3), hlm. 165181. doi: 10.1007/s10671-008-9050-5.

National Council of Teachers of Mathematics [NCTM]. 2000. Principles and Standards for School Mathematics. Reston, Va.: National Council of Teachers of Mathematics.

Özsoy, G., \& Ataman, A. 2009. "The Effect of Metacognitive Strategy Training on Mathematical Problem Solving Achievement". International Electronic Journal of Elementary Education, 1 (2), hlm. 6883.

Pajares, M.F. 1992. “Teachers' Beliefs and Educational Research: Cleaning up a Messy Construct". Review of Educational Research, 62 (3), hlm. 307-332. doi: 10.3102/00346543062003307.
Redhana, I. W. 2012. "Model Pembelajaran Berbasis Masalah dan Pertanyaan Socratik untuk Meningkatkan Keterampilan Berpikir Kritis Siswa". Cakrawala Pendidikan, XXXI (3), hlm. 351-365.

Redhana, I. W. 2014. "Pengaruh Model Pembelajaran Seminar Socrates terhadap Hasil Belajar Siswa". Cakrawala Pendidikan, XXXIII (1), hlm. 27-38.

Schoenfeld, A. 1992. "Learning to Think Mathematically: Problem Solving, Metacognition, and Sense Making in Mathematics", dalam D. A. Grouws (Ed.), Handbook of Research on Mathematics Learning and Teaching. New York: Macmillan. HIm. 334-370.

Steven, D. D., \& Levi, A. J. 2005. Introduction to Rubrics. Sterling : Stylus Publishing.

Sutton, M. J. 2003. "Problem Representation, Understanding, and Learning Transfer: Implications for Technology Education Research. Journal of Industrial Teacher Education, 40 (4), hlm. 47-61.

Western and Northern Canadian Protocol for Collaboration in Education [WNCP]. 2006. Rethinking Classroom Assessment with Purpose In Mind: Assessment for Learning, Assessment as Learning, Assessment of Learning. Manitoba: Manitoba Education, Citizenship and Youth.

Wolf, D., Bixby, J., Glenn, III. J., \& Gardner, R. 1991. "To Use Their Minds Well: Investigating New Forms of Student Assessment". Rev. Res. Educ. 17, hlm. 31-73. 